\title{
Readers' Disgust in the Case of Rebekah, Jacob, Isaac, and Esau: Perverters of Justice?
}

\author{
GERRIE F. SNYMAN (UNISA)
}

\begin{abstract}
Popular readings, for example, sermons appear to exonerate Rebekah and Jacob (Gen. 25: 19-34; Gen 27-29, 33), as if they want to salvage the relation between faith and good character. Scholarly readings are more ready to question Rebekah and Jacob on a continuum between Rebekah and Jacob as deceitful and rescuing the Abrahamic covenant. Who are to be regarded as the perpetrators perverting justice in this narrative? In this essay, I would opt for Esau as the injured party of the fraud perpetrated by his mother and brother. The argument starts with the notion of moral perversity as framed by the concept of moral injury as well as disgust expressed at moral digressions. This discussion will be followed by an explanation of four sermons on Jacob, Esau, Rebekah, and Isaac. The argument will be directed to a discussion of selected scholarly interpretations of the story cycle.
\end{abstract}

KEYWORDS: Rebekah, Jacob, Esau; Isaac, Perpetrator Studies, Sermons, Covenant, Reception, Contextualisation, Ethics of Interpretation, Decolonization, Postcolonialism

\section{A INTRODUCTION}

In this study, I employ perpetrator studies as a theoretical framework to interpret Isaac and Rebekah, Jacob and Esau's story cycle. For this study and given the social context of a lockdown for Covid 19, I decided to look at sermons on these four characters and compare them with what I could find in a selected set of scholarly articles. A few popular readings (sermons) on this narrative appear to exonerate Rebekah and Jacob, as if they want to salvage the relation between faith and good character. Scholarly readings, on the other hand, more readily question Rebekah and Jacob.

Perpetrator studies is a relatively new study field that aims to understand the issue of perpetration within victims' context but from the point of view of perpetrators. Refusing to investigate perpetrator behaviour allows perpetrators

\footnotetext{
* Submitted: 26/08/2020; peer-reviewed: 25/11/2020; accepted: 26/11/2020. Gerrie F. Snyman, "Readers' Disgust in the Case of Rebekah, Jacob, Isaac, and Esau: Perverters of Justice?" Old Testament Essays 33 no. 3 (2020): 445-472. DOI: https://doi.org/10.17159/2312-3621/2020/v33n3a6.
} 
an influence they do not deserve. To unmask perpetrators' behaviour does not result in condoning their actions or presenting them with a forum to excuse their actions. ${ }^{1}$ As Hannah Arendt has argued with Adolf Eichmann's trial (a Nazi perpetrator caught in Argentina in 1960 and sentenced to death in 1962 in Israel), most perpetrators are ordinary human beings acting extraordinarily in unusual and obscure circumstances. In normal situations, their actions will be ordinary. However, situate them in the context of a grey zone, ${ }^{2}$ ordinary people become perpetrators who would do horrible things to other people - things they will never do in normal or ordinary circumstances. Therefore, representing perpetrators is problematic because a perpetrator would see him- or herself in a different way than their victims would and third parties present them with a complex web of different interacting worlds, either with the aim to hold them accountable or to exculpate them.

The Jacob and Esau story cycle (Gen. 25: 19-34; Gen 27-29, 33) presents the reader with a densely woven description of the characters of Rebekah, Isaac, Jacob, and Esau. Interpretations provide the researcher with a multiplicity of layers instrumental in understanding their actions and behaviours. At face value, the story portrays Esau as the antagonist, the evil character who despised his birthright (Gen 25:34). The actions of the other three characters aim to ensure that Jacob receives the benefits of the birthright he purchased. The actions of Rebekah and Jacob are deceitful, while Isaac seems to be oblivious of what is transpiring.

The story is very pronounced in its problematisation of Esau's character: the narrator declares him casual and unconcerned about his rights as the firstborn. However, no judgement is reserved for the lies of Rebekah, and Jacob's complicity. Deception seems to be part of Rebekah's family when one takes her brother Laban's deceptions into consideration. Since Jacob, in turn, experiences deception at least twice in his life, one can argue that as a fraudster, he gets his just rewards. Isaac does not figure prominently in the story. In contrast to Abraham, he is absent in the choice of wives for Esau, and his role in providing for the blessing of Esau is questionable.

The question is: Who perverts justice, and for whom should the readers reserve their disgust? Is it Rebekah and Jacob for deceiving Isaac, and robbing Esau of his blessing? Is it Jacob for exploiting Esau's nonchalance regarding his birthright? Is it Esau for neglecting the birthright tradition, or is it Isaac for neglecting his role as patriarch? In the major prophets, Esau is depicted as providing some redemption measure for his progeny associated with his name,

1 See Kara Critchell, Susanne C. Knittel; Emiliano Perra; and Ugur Ümit Üngör, "Editor's Introduction," Journal of Perpetrator Research 1/1 (2017): 1-27.

2 See Primo Levi, The Drowned and the Saved (Vintage Books, New York, 1989), 36-69. 
Edom (Isa 34:1-17; 63:1-6; Jer 49:7-22 and Ezek 25:12-14 and 35:1-15). The minor prophets, however, cannot contain their disgust for Esau or Edom (Am 9:11-12; Joel 4:19-21 and Mal 1:2-5). ${ }^{3}$ The two references to Esau in the New Testament continue this negative trend (Heb 12:16; Rom 9:10-13).

In line with my research on perpetrators ${ }^{4}$ and associative as well as cathartic identification with Esau, ${ }^{5}$ I opt for Esau as the injured party of the fraud perpetrated by his mother and brother. They perverted the justice that Isaac sought to provide in the light of Esau's status as the firstborn, despite the story laying the blame on Esau. I do not share the disgust for Esau. I intend to argue my case while providing implied (gender?) criticism to those readings that tend to turn Rebekah into a hero and the champion of the Abrahamic covenant and minimise Isaac's role as the second patriarch.

I am not sure how to understand Isaac's role and function in the narrative. There is no hint in the story that Isaac knew that he is being deceived. As patriarch, he serves as the conduit for all decisions, and the other characters act around him. Yet, interpretations redeeming Rebekah and Jacob's ruse on the basis of male domination within patriarchy (that is, to keep Yahweh to his promise to Abraham's progeny), to my mind border on moral perversity, ${ }^{6}$ which is a problem that keeps rearing its ugly head in the reconstruction of a postapartheid South African society.

This essay is structured in three main parts. It starts with the notion of moral perversity in terms of moral injury, as well as disgust expressed at moral

3 For a contrastive list of Edom or Esau as either good or bad, see footnote 9 of Ehud Ben Zvi, "Edom as a Complex Site of Memory Among the Literati of Late Persian/early Hellenistic Judah: Some Observations," https: //www.academia.edu /40823705/BenZvi_Edom_as_a_Complex_Site_of_Memory_academia.edu_version. (2020).

4 Gerrie F. Snyman, "A Hermeneutic of Vulnerability: Redeeming Cain?" Stellenbosch Theological Journal (2015) 1 2/3: 633-665. DOI: http://dx.doi .org/10.17570/stj.2015.v1n2.a30; "Read as/with the Perpetrator: Manasseh's vulnerability in 2 Kings 21:1-18 and 2 Chronicles 33:1-20," Scriptura (2017) 116/2: 188-207. Doi: 10.7833/116-2-1318, "Perpetrator silence: Obadiah's depiction of Israel as victim and Edom as perpetrator," in Vulnerability and Resilience, Uta Schmidt (ed.). To be published.

5 Gerrie F. Snyman, "A Hermeneutic of Vulnerability: Edom in Malachi 1:2-5," JSem (2016) 25/1: 595-629; "Obadiah and a hermeneutic of vulnerability," in Obadiah. Readings: A New Biblical Commentary (ed. Bob Becking, Sheffield Phoenix Press: Sheffield, 2016), 45-63.

6 See Gerrie F. Snyman, "The Ethics of reading the Bible: Vulnerability in and moral injury of whiteness in (white) Bible reading," paper read at conference on The abuse of religion and the gullibility of the public at Unisa in March 2019. Publication forthcoming. 
digressions. This discussion will be followed by a brief explanation of four sermons on Jacob, Esau, Rebekah and Isaac. In the next section, a selection of scholarly interpretations of the story cycle will be discussed. A final concluding section will draw the threads of the discussion together.

\section{B MORAL PERVERSIONS}

\section{Moral injury}

In her book on the discourse of fundamentalism and its failure to account for the socio-political location of the reader, Kathleen C. Boone argues that there are two consequences to this failure. The first is the considerable power the pastor as informed bible reader holds over the audience, who does not possess the knowledge to question his or her interpretation of the biblical text. The pastor's power seems to linger in the text, equating his or her interpretation with divine authority: "Parties to conflict believe they have God on their side, and those completely outside the discourse are perceived either as lost souls to be won or enemies to be beaten." who as lay readers of the text are left in a state of ethical paralysis, aware of interpretative abuses but powerless to bring them to light, because of the hidden nature of the interpretative authority of the interpreter: "One stands a far better chance of challenging a revealed authority than a hidden one, and one stands hardly any chance at all when that hidden authority is parading in the guise of holy scripture." "With the Bible as the Word of God, the interpreter is implicitly cast as simply doing and saying what God pronounces in his word, as Heinrich Bullinger (Zwingli's successor) asserts in his Second Helvetic Confession, Article 1: Praedicatio Verbi Dei Est Verbum Dei. ${ }^{9}$

These consequences were very real in South African politics from 19481994 under the rule of the National Party and its representation of Afrikaner Calvinism and the policy of apartheid. The ethical paralysis within the Afrikaans reformed traditions regarding apartheid caused a moral injury in the midst of their faithful. Apartheid was damaging also to the humanity of those who supported the policies, rendering the Afrikaans reformed tradition culpable.

In mentioning the Afrikaans reformed churches, I am not claiming "facile victimhood" or "passive collaboration." 10 The ethical paralysis I assume relates

7 Kathleen C. Boone, The Bible Tells Them So. The Discourse of Protestant Fundamentalism (London: SCM Press, 1990), 111.

8 Boone, The Bible Tells Them So, 111.

9 Ronald Baines, “'Praedicatio Verbi Dei Est Verbum Dei:' The Preaching Of The Word Of God Is The Word Of God - Heinrich Bullinger And The Second Helvetic Confession," JIRBS 2 (2015): online: https://www.galaxie.com/article/jirbs02-0-02.

${ }_{10}$ With regard to the film Moffie which is about white male conscription in the army during the middle to late apartheid years, Sekoetlane Phamodi, (Phamodi, Sekoetlane. 
to a parallel phenomenon after the USA's Vietnam war when soldiers suffering from Post-Traumatic Stress Disorder (PTSD) revealed a moral injury when they returned from the battlefield. Jonathan Shay defines moral injury as a betrayal of what is right by someone who holds legitimate authority (e.g. a military leader) in a situation involving serious risks. ${ }^{11}$ Moral injury occurs when particular social, political, religious and cultural perspectives create a hostile environment. ${ }^{12}$

One of the consequences of moral injury is that a person's self-value becomes affected - a sense that one is unable to function properly in society. ${ }^{13}$ Experiencing a loss of self-worth may be accompanied by a collapse of one's moral architecture, as well as a feeling of being disconnected from society. When this happens, a person may doubt the impact he/she may have in society. Moral injury entails a betrayal of what is right, it creates poisonous relationships, and its impact can be seen in the way justice is understood in society. Poisonous knowledge has a direct impact on epistemology, causing within a person not only an epistemic dissonance but often also a moral and bodily dissonance. ${ }^{14}$ Such dissonance is still evident in South Africa in racial discourse when, from a position of whiteness, the effects of apartheid are ignored as the result of a willful cognitive ignorance that has been cultivated during apartheid.

Evidence of such wilful cognitive ignorance is then not surprising in the statement (later retracted) by the Former President FW de Klerk Foundation that

\footnotetext{
"Opinion: Hermanus's Acclaimed 'Moffie' is Probably Not for Black Queers." okayafrica.com (2020): https://www.okayafrica.com/south-africa-reframed-oliverhermanus-moffie-film-critique/ --my italics) in a very empathic yet deep-cutting review of the film, argues as follows: "The film is set in a particular moment in South Africa's recent history, where these white characters in a white army have a distinctly white experience under a white supremacist social order. But its decided refusal to examine the cost of their context and choices to their and our collective humanity only edifies the tired trope of South Africa's whites as apartheid's facile victims rather than its passive collaborators."

11 Jonathan Shay, Achilles in Vietnam. Combat Trauma and the Undoing of Character (New York: Touchstone Books, 1995), 183.

12 Joseph Wiinikka-Lydon, "Moral Injury as Inherent Political Critique: The Prophetic Possibilities of a New Term," Political Theology 18 (2017): 219-32.

13 Joseph Wiinikka-Lydon, "Dirty Hands and Moral Injury," The Royal Institute of Philosophy 93 (2018): 365.

14 Wiinikka-Lydon, "Moral Injury as Inherent Political Critique," 225, 228 defines "poisonous knowledge" as "the unwanted awareness that one's family, friends, social relationships - what one takes for granted as for one-may fail" in the end. Such knowledge poisons one's world-view resulting into despair and loneliness, even a sense of betrayal.
} 
apartheid was not as bad as others seem to portray it. ${ }^{15}$ This type of interpretation of apartheid testifies to a particular ethical paralysis about the nature of the policy and its racial bias. The response to the former president was vicious. The Economic Freedom Fighters (EFF) was the most vociferous and even went to the extent of public display at the State of the Nation address in February 2020 demanding that De Klerk should leave the gallery of Parliament. Such action was intended to show a disgust to match what was believed to be De Klerk's moral perversity in his claims about apartheid. De Klerk was called a murderer and an unrepentant apologist of apartheid. ${ }^{16}$ De Klerk had opened a festering wound with the statements he uttered in the SABC interview. In the light of him being the last white president of South Africa, and a symbol of the last apartheid regime (although his reforms and policies paved the way for the transmission of power to a black majority), and especially in the light of his recent criticism of the UN's stance on apartheid (his foundation withdrew his statement), the EFF found his presence at the opening of Parliament "an affront to citizens of the country's hard-won democratic order," in the words of Brooks Spector verbalising Julius Malema. ${ }^{17}$ The anger was genuine and widespread, portraying white people in

15 According to a timeline of the events, the following is reported in The Citizen: of 17 February 2020 (Sesona Ngqakamba, "TIMELINE | FW de Klerk: Tracking the storm," https://www.news24.com/SouthAfrica/News/timeline-fw-de-klerk-tracking-thestorm-20200217):

"Towards the end of one interview, SABC's political reporter, Manelisi Dubase, asked De Klerk for his thoughts on the United Nation's declaration that apartheid was a crime against humanity.

De Klerk replied: 'I don't fully agree with that. I'm not justifying apartheid in any way whatsoever. It did [wreak havoc for millions of South Africans, as Dubase put it] and I apologised for that. I profusely apologised for that.

"But there is a difference between calling something a crime. Like genocide is a crime. Apartheid cannot be, for instance, compared with genocide. There was never genocide," De Klerk said.

Although Dubase mentioned that apartheid played a role in mass killings, De Klerk said more people 'died because of black-on-black violence than because of apartheid'." De Klerk withdrew his statement a few days later.

16 See Sesona Ngqakamba, "TIMELINE | FW de Klerk: Tracking the storm," https://www.news24.com/SouthAfrica/News/timeline-fw-de-klerk-tracking-the-storm -20200217).

17 J. Brooks Spector, "The four ages of Frederik Willem de Klerk," Article. Daily Maverick 20 February 2020. https://www.dailymaverick.co.za/article/2020-02-21-thefour-ages-of-frederik-willem-de-klerk/. For more criticism within Afrikanerdom, see Antjie Krog, "FW de Klerk never had any moral intention, and he left us behind as white kansvatters," Analysis News24, 21 February 2020, https://www.news24.com/Analysis/antjie-krog-fw-de-klerk-never-had-any-moralintention-and-he-left-us-behind-as-kansvatters-20200220 and Lindie Koorts, "No shame, no remorse: How Afrikaners are dealing with their apartheid past," Analysis 
the words of the poet, Antjie Krog, "as a community of white kansvatters (chancers)..."18

\section{Rhetoric of disgust}

The rhetoric of disgust was very clear in the request to remove De Klerk from the public gallery: he was depicted as a murderer and unapologetic of apartheid. The source of disgust here is morality: De Klerk's stance towards apartheid makes him morally unclean. He became someone from whom people needed to be kept at a distance, whose presence contaminates those around him, someone who needs to be excreted by society. The laws of purity and uncleanliness in the Old Testament helps one to understand this disgust.

Eva Levavi Feinstein, based on the purity laws in the Hebrew Bible, argues that purity and pollution are inherent in the way individuals and society think and behave.$^{19}$ Feinstein sees a close correlation between what people now see as disgust and pollution in the Hebrew Bible. She refers to "food, body products, animals, sexual behaviors, contact with death or corpses, violations of the exterior envelope of the body such as gore and deformity, poor hygiene, interpersonal contamination (contact with unsavory human beings), and certain moral offenses." ${ }^{20}$

The notion of disgust is a complex emotion in the web of culture, developed in part from human bodily experience. Disgust is a response to various threats: "Disgust makes us step back, push away, or otherwise draw a protective line between the self and the threat." 21 Food, animals, and body by-products may cause feelings of disgust. This type of disgust is associated with revulsion (as revealed in facial expressions) and nausea. ${ }^{22}$ Hence there are prohibitions on what kind of animals can be eaten and a taboo on animals as sexual partners

News24, 20 February 2020; https://www.news24.com/Analysis/analysis-no-shame-noremorse-how-afrikaners-are-dealing-with-their-apartheid-past-20200220.

${ }_{18} \mathrm{Krog}$, "FW de Klerk never had any moral intention," https://www.news24.com IAnalysis/antjie-krog-fw-de-klerk-never-had-any-moral-intention-and-he-left-usbehind-as-kansvatters-20200220.

${ }_{19}$ Eva Levavi Feinstein, Sexual Pollution in the Hebrew Bible (Oxford University Press: Oxford, 2014), 4-5.

${ }^{20}$ Ibid, 24.

${ }^{21}$ Jonathan Haidt, Paul Rozin, Clark McCauley and Sumio Imada, "Body, Psyche, and Culture: The Relationship between Disgust and Morality," Psychology and Developing Societies 9/1 (1997): 127.

22 Paul Rozin and April E. Fallon, "A Perspective in Disgust," Psychological Review 94/1 (1987): 25. They provide various theories for the emotion of disgust: animality, spoilage and decay, distance from humans, anomaly, and feces as primary disgust substance. 
(bestiality). ${ }^{23}$ The excretion of body products is also an object of core disgust because it contaminates. A dead body (and death) is the epitome of such contamination. The sensitivity of contamination enables one to avoid pollution and maintain purity. ${ }^{24}$ This basic fear of contamination, or aspiration to cleanliness and purity, is extended to the socio-cultural realm of good and evil: "Human societies take advantage of the schemata of core disgust in constructing their moral and social lives, and in socialising their children about what to avoid." ${ }^{25}$ In this respect, for example, if one wishes to show dominance over another, contact between your body and that of the (usually) hostile other is effected by having the hostile other kissing your hand or foot. In other words, a vulnerable part of the hostile body (mouth) touches a less vulnerable part of the one with power. The submissive individual is forced to come into contact with any bodily excretion of the dominating other. ${ }^{26}$

The social body works more or less in the same way. Human bodies identify with each other within a social unit, functioning as a holistic organic system. Anyone, who violates the group's norms and values, is regarded as pathogens that threaten to infect the social body. Outsiders, enemies, moral offenders are viewed as dirty and repugnant by the social body, which shows its disgust quite viscerally, as was the case recently at the opening of Parliament. Feinstein formulates this as follows:

From an evolutionary point of view, disgust at outsiders literally protects the group and its members from novel pathogens. Yet such group-based disgust can also be recruited to defend groups or tribes from a wide variety of real and perceived harms. ${ }^{27}$

Psychological studies indicate a close relationship between disgust and morality. As Feinstein summarises, "an emotion that primarily protects the boundaries of the physical body is applied, through learning and cultivation, to matters that may not include the body at all." ${ }^{28}$ There is a connection between the sensation and bodily attributes of disgust and moral judgment. ${ }^{29}$ Culture and education determine which entities generate disgust. ${ }^{30}$ Disgust appears in

\footnotetext{
23 Haidt et al., "Body, Psyche, and Culture," 112-114.

24 Ibid., 116.

25 Ibid., 124.

${ }^{26}$ Paul Rozin, Carol Nemeroff, Matthew Horowitz, Bonnie Gordon and Wendy Voet, "The Borders of the self: Contamination sensitivity and Potency of the Body Aperture and other Body Parts," Journal of Research in Personality 29 (1995): 338.

27 Feinstein, Sexual Pollution in the Hebrew Bible, 29.

${ }^{28}$ Ibid., 34. Feinstein also refers to studies where the link between disgust and moral judgment is weak.

29 Ibid., 34.

${ }^{30}$ Feinstein, Sexual Pollution in the Hebrew Bible, 36.
} 
culture-specific forms in relation to whether the disgust elicitors are enhanced or downplayed. ${ }^{31}$

Disgust is a very basic emotion, but in human societies, it has become rather complex, and extends beyond mere survival. As an innate response, disgust serves our survival instincts, especially with regard to food: bitter-tasting food is less likely to be nutritious than sweet tasting fruit. Disgust further developed in human beings to enable them to preserve themselves on moral and spiritual levels. Heather Looy thus defines disgust as follows:

Disgust is deeply rooted in our bodies, both viscerally and neutrally, and therefore reflects our embodiment and evolutionary history. Disgust is a "moral emotion"- that is, its particular function is to facilitate evaluations of good and bad, rightness and wrongness, and to motivate and direct behaviour away from the bad. The triggers of disgust are learned in the community and play a crucial role in cultural identity, revealing our embeddedness and relationality. Finally, many disgust triggers are linked explicitly to divine expectations and demands, reflecting human spirituality. ${ }^{32}$

One of the major functions of disgust is to enforce adherence to moral laws. ${ }^{33}$ Morality, in turn, is expressed through emotions, embedded in human relationship and emotional connection. ${ }^{34}$ However, disgust, as an emotion, does not determine morality. ${ }^{35}$ People showing intense disgust are not necessarily more likely to adhere to a specific moral code.

Social boundaries determine whether contact pollutes and elicits disgust. At the State of the Nation Address (SONA), such a boundary was created by the EFF in portraying Former Pres. De Klerk as a murderer and someone who failed to apologise for apartheid. They used a language of pollution that contained the notion of contamination and disgust in order to elicit a similar response in Parliament.

Yet one wonders what moral code allowed Former Pres. De Klerk to try to redeem apartheid? Was it an effort to redeem his ancestors who introduced apartheid as political policy, and who justified it theologically? Nonetheless, the effects are clear on me: here I am, the white, masculine, Afrikaans, Christian, middle class, author of this essay, perverted by my tribal leaders into a kansvatter, a perpetrator of apartheid, irredeemably linked to a crime against

31 Feinstein, Sexual Pollution in the Hebrew Bible, 39.

32 Heather Looy, "Embodies and Embedded Morality: Divinity, Identity, and Disgust," Zygon 39/1 (2004): 222.

33 Ibid., 225.

${ }^{34}$ Ibid., 230.

35 Ibid., 231. 
humanity, while I am trying to read what the Bible says and does to kansvatters - chancers, fortune seekers, someone not to be trusted and thus without integrity.

With which perpetrator should I side, with Esau, or Jacob and Rebekah? Jacob with Rebekah are the heroes in the narrative, and their trickery is glossed over while Esau has to bear the brunt in the end, with his progeny Edom becoming prime evil in Hebrew scriptures. Why would one want to redeem Esau when the story already evaluates him negatively? Or to put it differently: why not reserve outrage and disgust for the moral perversity committed by Rebekah and Jacob? Why are they Disneyfied? ${ }^{36}$

In the next section, the sermons I discuss provide some examples of the Disneyfication of Rebekah and Jacob and how difficult it is to come to terms with their deceit.

\section{RECEPTION OF THE JACOB-ESAU CYCLE IN SERMONS}

My sympathy towards the likes of Esau is known, although Malachi 1:2-5 and Hebrews 12:15-16 make it rather difficult to have sympathy for Esau: "Once portrayed as a perpetrator it seems to be rather difficult if not impossible to be redeemed. And if the perpetrator is not going to read or hear what is being said, it becomes a counterfoil for the wrath of someone else." ${ }^{37}$ When one reads sermons based on this story in Genesis, it becomes clear that Esau is very much a symbol of hate in the reading tradition, which is quite evident in the treatment Edom receives. When Edom can be portrayed as treasonous, it becomes rather unproblematic to read into Esau or Edom's references this anti-Esau/Edomite trend. A chiastic structure in Malachi 1:2-5 supports an anti-Edomite perspective, ${ }^{38}$ but in this case one may ask whether the chiastic structure is constructed from an anti-Edomite perspective in the first place, or whether it proves an anti-Edomite perspective. ${ }^{39}$ What seems clear is that the history of interpretation of Esau is so deeply influenced by an anti-Edomite perspective that it is difficult to determine which came first.

Published sermons on Jacob and Esau are not that easy to come by within a South African context, and I settled for two Afrikaans sermons (within the RCSA Rev. Danie Snyman in Pretoria and within the DRC, Rev. Chris Saayman from Cape Town, both within the narrow Afrikaans Calvinist tradition) and two sermons on sermoncentral.com, one from the American evangelical tradition

\footnotetext{
${ }^{36}$ For a discussion of the term, see below in section D.

37 Snyman, Gerrie F. "A Hermeneutic of Vulnerability. Edom in Malachi 1:2-5," JSem 26/2 (2016): 625.

${ }^{38}$ Fanie (S.D.) Snyman, Malachi (Leuven: Peeters, 2014), 30-31.

39 Snyman, "A Hermeneutic of Vulnerability," 626.
} 
(Rev. Matthew Kratz) and another from the American reformed tradition (Rev. Freddy Fritz).

Looking at this story's reception in sermons ${ }^{40}$ it becomes evident how resilient the theological structures are that relieve Jacob and Rebekah of culpability yet keep Esau in a stranglehold of guilt and shame for not valuing his birthright, for marrying Hittite women and not despising them, or for finding solace in the veld and the wild.

Matthew Kratz ${ }^{41}$ in his sermon sees in Rebekah a lesson in struggling through a disappointed, distressed, and divided home. Rebekah remained childless for a long time, and only conceived after the prayerful intervention of her husband. The story relates that the pregnancy was difficult, because the children struggled within her, making the pregnancy extremely uncomfortable.

How the two boys were born would also become the way of their life: Esau, the hairy and reddish one, named after his looks, and Jacob, gripping the heel of his brother, named after his actions, alluding to deceit already early in the story. Kratz argues that the two boys' description matches their spiritual state: ${ }^{42}$ Jacob belonging to Yahweh and Esau not, hence indicating a divided home. Esau is put at a disadvantage from the start, as he is not the deity's choice. On the other hand, Jacob becomes an example of divine sovereign election, based on Romans $9 .^{43}$

According to Fritz, if Isaac knew of Rebekah's struggle during her pregnancy, it can be assumed that he knowingly intended to give Esau the covenant blessing, causing Rebekah to resort to fraud to counter Isaac's actions and to enable Yahweh's oracle to come true. ${ }^{44}$ Reading the narrative from this point of view, Isaac becomes culpable in that he seems to allocate the blessing secretly, "defiantly disobey[ing] the clear will of God and sought to pass the

40 I chose these sermons based on Google with the words "Jacob," "Esau," Rebekah," "Genesis 32, "Genesis 33" and "sermon."

41 Matthew Kratz, "Rebekah: The Mother of Jacob and Esau," Sermon Central, May 12, 2017. https://www.sermoncentral.com/sermons/print?sermonId=208912 [accessed 23 March 2020].

42 Kratz, "Rebekah," 6: "It suggests that Jacob belonged to the people of God whereas Esau did not. The Garden of Eden was separated off from the uncultivated, open field where the non-domesticated animals roamed. Later, the tents of the Israelite camp were separated off from the unclean, open area outside the camp. Jacob belonged with his people in the camp, 'dwelling in tents', but Esau belonged outside."

43 Kratz, "Rebekah," 5.

44 Freddy Fritz, "Jacob's Deception of Isaac," Sermon Central (2017): Accessed 23 March 2020, https://www.sermoncentral.com/sermons/jacob-s-deception-of-isaacfreddy-fritz-sermon-on-deception-227090. 
blessing along to his rebellious son, Esau. ${ }^{~} 45$ But the text in Genesis does not portray Esau as rebellious. His rebellious nature is only mentioned in the reception of the Esau tradition in the New Testament, in Hebrews 12:15-17, where Esau is depicted as unholy. ${ }^{46}$

In the sermon by Danie Snyman, the situation is depicted differently. If Isaac did not know about the oracle, Rebekah's and Jacob's behaviour becomes completely fraudulent. This fraud is not accounted for, because Jacob is regarded as predestined to receive the birthright as well as Isaac's blessing. ${ }^{47}$ When the will of the deity is fulfilled, the deceivers still fall under the grace of the deity. Those outside of that grace will never be redeemed, not even in the way they are portrayed in narratives. In Danie Snyman's sermon, Jacob and Esau have equal opportunities. They both came from the same stock with the same parents. They were even twins, and one was not more successful than the other. The crux of the matter was that Jacob had the deity behind him and not Esau. Thus, the depiction of Esau is not favourable. He is castigated for despising his birthright, and for taking Hittite women as his wives, thereby creating a gross irritation for his mother, who clearly questioned his choice for wives. ${ }^{48}$

Within the reformed tradition of which Fritz and Snyman are part, the story's reception is linked to the triumph of God's will, despite the actions of Rebekah, Isaac or Jacob. In the third sermon within the reformed tradition, that of Chris Saayman, the doctrine of predestination forms the point of departure for interpreting the story. Following the point of Esau's contempt for tradition in his birthright and choice of wives ${ }^{49}$ the implication is that such an insolent person can never fulfil the will of God. Isaac is regarded as acting against God's will with Esau a willing participant in Isaac's plan. Rebekah is the expert schemer and outsmarted Isaac, who believed Jacob's ruse by smelling Jacob's clothes and hair, thinking it is Esau. Jacob stands in Esau's place, as Christ will stand in the faithful's place, argues Saayman. Saayman sees a foreshadowing of a particular Christian belief system in Jacob's fraud, namely the substitutionary sacrifice of Christ.

\footnotetext{
45 Ibid., 4.

46 Ibid., 6.

47 Danie Snyman. "Agter ons Lewens lê God se Beskikking," Gereformeerde Kerk, Magalieskruin, Preke (2012): Accessed 23 March 2020, 2020. http://www .gkmagalieskruin.co.za/View/ShowDoc.aspx? WebID =101\&ImageID=470.

48 See also Fritz, "Jacob's Deception of Isaac," https://www.sermoncentral .com/sermons/jacob-s-deception-of-isaac-freddy-fritz-sermon-on-deception-227090.

49 Chris Saayman, "Genesis 27: Die mens wik maar God beskik," Preke: Genesis reeks no. 26, 9 February 2019, http://www.tafelbergkerk.co.za/sermon/genesis-reeks-no-26die-mens-wik-maar-god-beskik/.
} 
Kratz too, from an evangelical side, emphasises Jacob's predestination and labels it "divine sovereign election." ${ }^{50}$ With Esau outside in nature and Jacob inside the tent camp, their geographical positions also display their spiritual predispositions. $^{51}$ In the process, even Isaac becomes complicit of acting deceitfully. His love for game dishes causes him to love Esau, which is interpreted as favouring one son above the other. ${ }^{52}$ Isaac's relationship to Esau is contrasted with that of Rebekah and Jacob. The latter relationship is not explained, but is interpreted as Jacob being "more interested in the promises that God had made to his father and grandfather." 53 Whereas Esau's commitment to daily sustenance was rejected as secular, Jacob's belief-system was heralded as his saving grace.

To conclude, in a sermon setting, the broader interpretative framework of the specific context in which and for whom the sermon is construed plays an important role. For example, within a (mostly South African reformed) Calvinist context Jacob, Rebekah and Isaac are traditionally painted in opposition to Esau in terms of predestination and divine election. Spero reminds the reader here of "layers of historical symbolism that have been laid upon Esau as evil Edom to the extent says that it is extremely difficult to obtain what he calls "an objective understanding" of Esau." 54 Nevertheless it is also important to look wider to see how the story cycle has been received in the scholarly interpretative tradition. ${ }^{55}$

\section{ESAU AND THE INTERPRETATIVE TRADITION: DISNEYFICATION OF FRAUD IN THE JACOB-ESAU STORY?}

From these four sermons as popular reception of the Jacob and Esau story, it becomes clear that interpreters find it difficult, if not impossible, to deal with Jacob and Rebekah's deceit. The preachers' whitewashing provided them with a sense of innocence and guarded them from disgust. The lack of disgust leads to applying the term "Disneyfication" as found in Henri Giroux's article. ${ }^{56}$ With Disneyfication and Giroux, I mean the construction or altering of a narrative into

\footnotetext{
50 Kratz, "Rebekah: The Mother of Jacob and Esau," 5.

51 Ibid., 6.

52 Ibid., 7.

53 Ibid., 7.

54 Shubert Spero, "Jacob and Esau: The Relationship Reconsidered," JBQ 32/4 (2004), 245-250.

55 At the time of writing, I was limited to literature I could find online due to a lockdown of the Corona virus. It would be worth another study to compare the results of this essay with what the scholarly tradition with reference to commentaries and books would argue. For this reason, the scholarly literature is not exhaustive, but as a selection of what was available at the time it gives one a fair idea.

56 Henri Giroux, "Animating Youth. The Disneyfication of Children's Culture," Socialist Review-San Francisco 24 (1994): 65-79.
} 
a simplified, sentimentalised, or contrived story: a pretence of innocence with protection from the interrogating critical gaze. ${ }^{57}$

How far would interpreters go to excuse Rebekah and Jacob in the story? Quite far, it seems, from (i) portraying Esau as the culprit rather than a victim of deception; to (ii) Rebekah and Jacob setting up a pious hoax; to (iii) where Jacob himself is thought to be deceived by his parents, causing him to think that he steals the blessing ${ }^{58}$ to (iv) where Isaac receives the blame for the deception. Let us start with Esau's portrayal as the culprit.

\section{$1 \quad$ Esau as culprit}

The trend to excuse adverse behaviour of heroic biblical characters already appeared in early Rabbinic literature, ${ }^{59}$ for example, Genesis Rabbah 67.4 attributes Jacob with mirmah, indicating wisdom in the sense of ingenuity and acumen, whereas Esau is portrayed as wicked. Jacob is idolised, and Esau vilified..$^{60}$ Even Haman of the Book of Esther gets here related to Esau via Amalek. Schindler is of the opinion that the contrasting depiction of the two brothers in Genesis Rabbah 67 reflects a particular eschatology, laying bare a "battleground [that] would lead through the ancient roads of Babylonia, Persia, and Edom and from the Second Temple period onward along the major highways of the Greek empire, Hellenism, Rome and early Christianity." 61 Esau's vilification in early Rabbinic literature makes Jacob's triumph, and feelings of disgust from the readers of the story, easier. Anderson refers to this as

57 Giroux, "Animating Youth," 67, refers to their trademarked innocence that is "unaccountable for the diverse ways in which it shapes the sense of reality it provides for children as they take up specific and sanitized notions of identity, difference, and history in the seemingly apolitical, cultural universe of the Magic Kingdom." With regard to Hutchinson (see below), the term is used anachronistically, as she lived and wrote long before Disney appeared on the scene, but her rendering of the fraudulent behaviour of Jacob and Rebekah is similar to what the Disney company has been doing for years with regard to the Brother's Grimm's fairy tales.

58 David J. Zucker, “The Deceiver Deceived: Rereading Genesis 27," JBQ 39/1 (2011): 46-58.

59 Pesach Schindler, "Esau and Jacob Revisited: Demon Versus Tzadik?” JBQ 35/3 (2007): 153-60.

60 Matthias Morgenstern, "The Image of Edom in Midrash Bereshit Rabbah" (pages 193-222 in Revue de l'Histoire des Religions (Online) nr. 2, 2016) argues that the depiction of Esau/Edom in Genesis Rabbah is influenced by the view at the time of Rome as the great evil.

61 Schindler, "Esau and Jacob Revisited," 157: The symbolism that portrays this conflict is a "useful camouflage to deflect the true identity of Israel's adversaries. Pragmatism dictated avoiding a reckless frontal confrontation with them." 
"triumphalism," ${ }^{\prime 62}$ which means that Jacob deserves his blessing and superiority over Esau, who is disregarded and ultimately denigrated as wicked. The contrast between the characters in Rabbinic literature also paves the way towards their Disneyfication of innocence and disgust in later receptions. In the end, even Esau's kiss is interpreted as a bite. ${ }^{63}$

Shira Weiss turns the sale of the birthright beneficial for both parties and eases the disgust for Esau. ${ }^{64}$ She argues that Esau's decision to sell his birthright was not a coercive choice and the price of lentil soup simply reflects the value he attached to his birthright, ${ }^{65}$ whereas Jacob's provision of the soup to his hungry brother constitutes an "act of virtue and beneficence." ${ }^{66}$ Esau found "no scruples about the ethics of his behaviour, nor did Esau question the propriety of Jacob's demand." ${ }^{\prime 67}$ Esau made the agreement after eating the soup and thus cannot claim coercion by Jacob in a moment of weakness because of hunger. One could rather accuse Esau of greed for satisfying his immediate cravings at the expense of spiritual welfare. ${ }^{68}$ But Weiss asks why Esau would have valued his birthright as the same as a pot of lentil stew? She finds her answer in Isaac's lack of wealth: he was in an impoverished state, and ultimately sent Jacob away with nothing in order to work for Laban. ${ }^{69}$

Weiss also mentions the problem in understanding Esau's action as a disregard for the firstborn's birthright. The birthright requires a sacrificial service by the firstborn. By selling his birthright, Esau tainted his status through an act of false worship as the family's firstborn. Jacob's buying of the birthright is then seen as a way to salvage the situation by expressing "a sincere piety that

${ }^{62}$ Bradford A. Anderson, "Jacob, Esau, and the Constructive Possibilities of the Other," BTB 49/1 (2019): 16-21.

${ }^{63}$ Mois A. Navon, "The Kiss of Esau," JBQ 35 no. 2 (2007): 128-31. Navon, "The Kiss of Esau," 128 refers to the interpretation of the word for "kiss" in the Hebrew where the pshat refers to a simple kiss, but the deeper meaning refers to Esau's continuous hatred that turned the kiss into a bite. Fortunately, Jacob's neck became stiff like marble and Esau's teeth broke and that is why he cried. Edward J. Bridge, "The 'Slave' is the 'Master': Jacob's Servile Language to Esau in Genesis 33.1-17." JSOT 38/3 (2014): 263-78 concludes that Jacob uses servile language to give the impression to Esau of his inferiority or self-deprecation and to have him accept his gifts as compensation for taking his blessing and birthright, forgoing his right of revenge.

${ }^{64}$ Shira Weiss, "The Ethics of Price Gouging. Jacob's Purchase of Esau's Birthright," JRE 45/1 (2017): 142-63 argues that moral ambiguities in the story enables multiple readings from the point of view of the price gouging debate.

${ }^{65}$ Weiss, "The Ethics of Price Gougin," 153.

${ }^{66}$ Weiss, "The Ethics of Price Gouging," 154.

${ }^{67}$ Ibid.

${ }^{68}$ Ibid., 159.

${ }^{69}$ Ibid., 155. 
was offended by the prospect of sacrifices being offered by the undeserving." 70 Accordingly, Esau is not seen as spiritually fit for the inheritance of the Abrahamic destiny, enslaved to desires of the body and marrying idolatrous wives, thereby violating Abraham's covenant. In contrast, Jacob is regarded as a God-fearing man. From a utilitarian point of view, Jacob was a far better choice than Esau as he would have made the best of the covenant. In fact, it is argued that Jacob cared more for his spiritual progeny than for his own personal welfare. ${ }^{71}$ Even when Jacob acts deceptively in pretending to be Esau, his ruse is justified on moral grounds as the best course to have taken, given the circumstances. $^{72}$

Taking the utilitarian point further is Elazar's remark that "the Bible tells us that a bright, calculating person who, at times, is less than honest, is preferable as a founder over a bluff, impulsive one who cannot make discriminating choices." ${ }^{73} \mathrm{He}$ based his remark on the different character traits he inferred from the two characters' behaviours in the story: Esau's disregard for his birthright when he was hungry and his contempt for Abraham's covenant in marrying forbidden women. Jacob finds favour with Elazar because of his intelligence and forethought in taking advantage of other persons in a deceitful way. ${ }^{74}$

Weiss and Elazar hint at Jacob and Esau as representing two aspects of human nature. Gary Inbinder takes the difference a bit further and interprets the two characters in terms of the foundations of Western philosophy. ${ }^{75}$ According to Inbinder, the difference is between "natural" and "civilised" man (sic), exemplified in their appearance and place of abode. ${ }^{76}$ With Jacob attuned to a higher nature of logic and spirit, Esau remains a man of the moment in his need to satisfy his hunger. Jacob thus did not take advantage of Esau's concupiscence. Esau simply lacked virtue and seized sensual satisfaction, whereas Jacob was drawn towards a transcendent virtue. ${ }^{77}$ With regard to birthright, Chaya Greenberger argues that Jacob did not cynically exploit Esau, but that Esau was to blame for not wanting to take up the responsibilities associated with the birthright in the first place. ${ }^{78}$ According to Jewish tradition (Rashi), the two brothers "redefined their roles in line with their individual natural tendencies,

\footnotetext{
70 Ibid., 156.

71 Ibid., 159.

${ }^{72}$ Ibid., 160.

73 Daniel J. Elazar, "Jacob and Esau and the Emergence of the Jewish People." Judaism 43/3 (1994): 294-301.

74 Elazar, "Jacob and Esau," 301.

75 Gary Inbinder, “Jacob and Esau,” Humanitas 26 no. 1 (2003): 90-96.

76 Inbinder, "Jacob and Esau," 90.

77 Ibid., 91.

${ }^{78}$ Chaya Greenberger, "Esau and Jacob: Brothers Clash, Reconcile and Separate," JBQ 46/3 (2018): 144.
} 
both legitimate." 79 This implies that Esau stays in the material realm and Jacob in the spiritual domain. With the blessing, however, Jacob also received the material domain, and Esau ended up despising Jacob for usurping the blessing and betraying their agreement. The story of Jacob and Esau, according to Greenberger, is not one of black and white existence, but an existence that matched the territory each brother staked out for himself: Jacob in Israel and Esau in Seir. ${ }^{80}$

\section{The role of Rebekah: pious fraud}

Within a Calvinist framework, the Jacob and Esau story cycle exemplifies the doctrine of predestination, subsequently enforcing a particular understanding of Jacob and Esau' characters, with Jacob as the legitimate heir to the blessing and birthright. It is clear that Rebekah succeeds in establishing Jacob as Israel, but her disobedience towards patriarchal authority does not go unnoticed by Calvin. He castigates Rebekah (with Sarah) for going beyond their faith to preserve the covenant lineage. He rebukes Rebekah as follows:

Rébecca, après que Dieu lui a révélé l'élection de Jacob, procure par mauvais et pervers artifice qu'il soit béni par Isaac (Gen. 27:6 ss), qui était témoin et minister de la grâce de Dieu; elle constraint son fils à mentir; bref, elle corrompt la verité de Dieu par plusieurs frauds et mensonges et, en exposant à oppobre et moquerie la promesse de Dieu, elle l'anéantit tant qu'elle peut. ${ }^{81}$

Within the $17^{\text {th }}$ century republicanism and matriarchy Rebekah became a symbol of female power. In a poem, Order and Disorder, ${ }^{82}$ Lucy Hutchinson

79 Greenberger, "Esau and Jacob," 145. Esau did not see himself fulfilling the legacy of the Abrahamic covenant which entailed total devotion to Yahweh and recognizing that Yahweh's way is the only way of justice and righteousness.

${ }^{80}$ Ibid., 155.

${ }^{81}$ Calvin, Jean. L'institution Chrétienne. Le Troisième Livre De L'institution Chrétienne. De La Manière De Participer à la Grâce De Jésus-Christ, Des Fruits Qui Nous En Reviennement Et Des Effets qui S'emn Ensuivent, (Genève: Editions Kerygma et Farel, 1978), 53 [III.2.31] my translation): "Rebeka, after God revealed to her the election of Jacob, obtained by bad and perverse ways the means for Jacob to be blessed by Isaac, the witness and servant of the grace of God. She forced her son to lie, in short, she corrupted the truth of God by various lies and deceits. Finally, she exposed as much as she could the divine promise to mockery and with shameful conduct she attacked the truth." Anderson, "Jacob, Esau," 17, shows how Calvin rebukes Rebekah and Esau, but Jacob is recommended for his spiritual foresight.

${ }^{82}$ Lucy Hutchinson was a poet, translator and biographer, married to Colonel John Hutchinson who was a signatory to King Charles's death warrant. After the restoration of the monarchy, he was thrown into jail and died in prison without a trial. Lady Lucy, an ardent Puritan with deeply held Calvinist convictions, wrote religious treatises of which a paraphrase of Genesis is one and published as Order and Disorder. 
rehabilitates Rebekah and Jacob by developing Rebekah as a typical matriarchal typological model who enabled the Christian narrative of redemption. As an essential matriarchal archetype, Hutchinson sanctifies Rebecca's "pious fraud" in the blessing narrative (18.75). ${ }^{83}$

In Hutchinson's representation, Rebekah's role as wife is in conflict with her role as a mother and "spiritual advisor." ${ }^{44}$ Rebekah had to counter her husband's neglect of God's plan to let the covenant line run through Jacob and not Esau. In the process, Rebekah is forced to deceive Isaac with what Hutchinson calls "pious fraud", in order to correct Isaac's miscalculation in trying to give the wrong son the blessing. But she also had to reckon with Jacob's cleverness and penchant for self-reliance. ${ }^{85}$ She does it by guile. ${ }^{86}$

To Guy Matalon, Rebekah's pious fraud is a hoax with long-lasting consequences. ${ }^{87}$ Rebekah would never see Jacob again once he departs to Laban, and Jacob would be tricked first by his uncle with Leah, and then by his own children in masking the disappearance of Joseph. ${ }^{88}$ Rebekah and Jacob faced the consequences of their actions; these consequences were emotionally draining and traumatic. ${ }^{89}$ To Matalon, their actions may simply show their human side with which God's ends are achieved. ${ }^{90}$ They are morally flawed, but according to Yair Zakovich it is precisely on the basis of these flaws that the readers can

${ }^{83}$ Lauren Shook, "'Pious Fraud': Genesis Matriarchs and the Typological Imagination in Lucy Hutchinson's Order and Disorder," Modern Philology 112/1 (2014): 181.

${ }^{84}$ Shook, "'Pious Fraud'," 197.

85 Leon R. Kass, “A Woman for All Seasons,” Commentary 92/3 (1991): 33.

${ }^{86}$ Kass, "A Woman for All Seasons," 33. Thanks to her ways, Rebekah is said to have brought Isaac and Jacob into alignment with each other and with Abraham so that Isaac can play his role as true father and patriarch to Jacob: "In the only way possible, not by force and not by confrontation, but by guile. But not by guile alone. At the same time, she acts with tact, delicacy, and affection; though she arranges her deception, she does whatever she can to preserve and promote the dignity of her husband, whom she serves out of love. By the end, Rebekah's Isaac rises to the work of transmission, and becomes truly the son of Abraham. [...] Rebekah holds her son through speech and command, and Jacob, like the true son of the covenant, listens, hearkens to her voice, and obeys." 87 Guy Matalon, "Rebekah's Hoax," JBQ 36/4 (2008): 243-51.

${ }^{88}$ Matalon, "Rebekah's Hoax," 248. Matalon based his argument on the narrative which takes Jacob to Laban and never mentioned him visiting his home again. Zakovich (1050) augments: "We have, therefore, one more measure-for-measure punishment of Jacob for his deceit toward his father. Where Jacob used his brother's clothes to delude his father, now he himself is duped by his sons with the use of their brother's garment. Furthermore, Esau's 'best' fetid garments were stained with the blood of animals he had hunted, while Joseph's garment was dipped by his brothers into kid-goat blood."

89 Matalon, "Rebekah's Hoax," 248.

90 Ibid, 250. 
draw lessons and improve themselves. ${ }^{91}$ Moreover, these flaws in the heroes' morality also provide some extenuating circumstances for their flawed behaviour. ${ }^{92}$ In Jacob's case, his character is slightly improved when the narrative in effect confirms Esau's own disgrace that would have made him rather unworthy of Abraham's blessing. ${ }^{93}$

In contrast to Matalon, it is discomfiting for Hutchinson to witness Rebekah's defect. Her status as a matriarchal archetype not only makes it necessary to condone her disobedience towards Isaac, but it is compulsory to close one's eyes to it, because Isaac put himself against God, and Rebekah's actions saved the day, which is called "pious fraud".

However, to be victorious, there needs to be an adversary. According to Shook, Hutchinson finds that in Isaac who supports his "reprobate" son, Esau, "the child of darkness," Isaac "lost the cheerful light" which even puts him at a distance from Jacob as the child of light. Shook formulates it as follows: "Rebecca's action is 'fraud,' but the blame clearly lies with Isaac, who allows his 'affection' rather than faith to 'govern' him" and "Compared to Rebecca and her 'pious fraud,' Isaac is the 'sinful' spouse who cannot 'comprehend' God's placement of Jacob over Esau." 95

In Hutchinson's poem, Shook argues that Isaac metaphorically murders Esau in what is understood to be a familial, or even civil war, with the parents fighting for their respective beloved sons. Isaac needed providence to ensure that the elected son is blessed. This is amply provided by Rebekah, who acts as an agent of providence, committing "pious fraud" not once, but twice. ${ }^{96}$ When Rebekah noticed Esau's anger and outcry, she realised Jacob was in danger and implored him to flee to her brother and hide until Esau's anger subsided. She tells Isaac a different story, namely that Jacob needed a non-Hittite wife, because Esau's Hittite wives gave her trouble, as daughters-in-law usually do (Gen 27: 46). However, because Rebekah is also related to Abraham's brother, Nahor, in

91 Yair Zakovich, "Disgrace. The Lies of the Patriach," Social Research 75/4 (2008): 1036: The heroes in the Bible merely convey "educational-ideological convictions of the biblical writers."

92 Zakovich, "Disgrace," 1050-1: In Jacob's case there appears to be favoured at least three extenuating circumstances: Isaac's preference for Esau as based on his taste for game, Jacob did not initiate the deceit, but his mother did, and Esau's Hittite wives' offensive behaviour towards their mother-in-law.

93 Zakovich, "Disgrace," 1054, adds that Isaac, in any case, never intended to give Esau Abraham's blessing.

94 Shook, "'Pious Fraud'," 198.

95 Ibid., 199.

96 Ibid., 200. 
sending Jacob to Laban, Shook concludes that Rebekah assumes a closer role towards upholding the covenant than does Isaac:

Rebecca's "pious fraud" is an ordained amalgamation of virtue and sin, as are the "wily arts" that God gifts to women "in recompense" for their inferiority to men. Women are permitted to and must resort to "pious fraud" for the benefit of their husbands and, indirectly, the kingdoms they govern. [...] Rebecca's fraud secures the blessing for Jacob and protects him from his brother's wrath. Specifically, for Rebecca, her fraud culminates in the providential matchmaking of Jacob and his future wives Leah and Rachel, "from whom great Israel's stock itself derives." ${ }^{97}$

\section{$3 \quad$ Jacob's piety?}

One interpretation that absolves Jacob from complicity in his mother's deception is Zucker's interpretation that Jacob was deceived by Rebekah as well as by Isaac. According to Zucker, there are clear indications in the text that Isaac and Rebekah know that Jacob is the designated heir, and they need to make it happen. There seems to be no tension between the two, and neither are they cursed when the ruse became known. In fact, when Jacob is sent away and blessed by Isaac, his actions are not those "of a man who feels duped and dishonoured by his wife and son," argues Zucker. ${ }^{98}$ Knowing that Jacob should be the heir, they were nonetheless incapable of telling it to Esau directly. Instead, they constructed a mistake in which Isaac gives the blessing to Jacob, and in the process cast Jacob as the villain..$^{99}$ Moreover, Jacob, the "homebody," 100 needs to be educated or trained in the vicissitudes of life, as life seems too easy for him. He needs to learn that he is capable of worldly behaviours and its consequences. ${ }^{101}$ Rebekah is seen as a loyal wife who would not "deceive, discredit, and dishonour her beloved husband." 102 In turn, Isaac is said to sense Jacob's discomfort when he enters the room with the food and is being questioned by Isaac regarding his identity, to the point that Isaac reassures Jacob with the words "the smell of my son is the smell of the fields." 103 Zucker has Isaac laughing inwardly at how well he and Rebekah accomplished the ruse. ${ }^{104}$ Isaac's trembling when Esau discovered the deception is linked to him feeling bad for the sake of Esau, and his inability to tell him the truth. ${ }^{105}$ Zucker sees a painful rite of passage for Jacob in the story,

\footnotetext{
97 Shook, "'Pious Fraud'," 200-1.

98 Zucker, "The Deceiver Deceived," 47.

99 Ibid., 48.

100 Ibid., 48

101 Ibid., 48.

102 Ibid., 49.

103 Ibid., 54.

104 Ibid., 55.

105 Ibid., 56.
} 
and a betrayal of faith for the sake of the continuation of the covenant. ${ }^{106}$ The effect it all had on Esau is minimised. It is as if he does not matter since he was not the elected one and part of the covenant in any case.

\section{Isaac's problem}

The role attributed to Isaac in the story increases or decreases to the degree in which Rebekah is thought to act deceptively or not. For example, in an essay aiming "to empower a statement of respect for Rebekah," 107 Moshe Reiss minimises the role of Isaac in order to provide for a determining role of Rebekah in ensuring the blessing is bestowed on the appropriate heir. ${ }^{108}$ In fact, due to Isaac's inabilities on various levels, Rebekah is regarded as the recipient of Abraham's blessing for posterity by ensuring that the right son receives the blessing, even when it meant deception and favouritism. Isaac is seen as being left traumatised by Abraham's willingness to kill him as a sacrifice, dependent for ever on his mother by living in her tents and not those of his father. ${ }^{109}$ As Reiss puts it, Isaac "is the weak son of a powerful father and the weak father of two powerful sons. His passivity is in striking comparison to his aggressive wife." 110

In contrast to this, Craig A. Smith sees the story as a commentary on Isaac, specifically on his failure to act as a patriarch is supposed to act, e.g. searching for a proper wife for his eldest son like his father Abraham did with him in finding Rebekah as a proper wife. ${ }^{111}$ Isaac's passivity causes Esau to choose unfit wives, creating tensions within Isaac's household. In fact, the subsequent tensions and dysfunctions in the family's story result from Isaac not fulfilling his duty as patriarch. ${ }^{112}$ In other words, if Isaac acted in accordance with his patriarchal duties, Rebekah would not have overstepped her cultural boundaries and resorted to deception. Jacob would have received the Abrahamic blessing

\footnotetext{
106 Ibid., 56.

107 Moshe Reiss, “The God of Abraham, Rebekah and Jacob,” JBQ 32/2 (2004): 91-

97.

108 Ibid., 96.

109 Ibid., 94.

110 Reiss, "The God of Abraham, Rebekah and Jacob," 97. Reiss's arguments were questioned on the basis of evidence by Ronald Hyman, "Comment on 'the God of Abraham, Rebekah, and Jacob'," JBQ 33/1 (2005): 61-64. Hyman accuses Reiss of not giving a fair assessment of either Isaac or Rebekah in failing to provide proper psychological evidence. In fact, Hyman disputes Reiss's evaluation of Isaac's passivity which he sees as contradicted by Isaac's success as a farmer as witnessed in Gen 26:1214.

111 Craig A. Smith, "Reinstating Isaac: The Centrality of Abraham's Son in the 'JacobEsau' Narrative of Genesis 27," BTB 31/4 (2001): 130-35.

112 Smith "Reinstating Isaac," 133.
} 
without becoming party to defrauding his brother deceptively from his blessing, thereby creating a family rift. ${ }^{113}$

There is no consensus on whether Isaac intended to give the blessing to either Esau or Jacob. The story manifests three blessings: Jacob gets two (one material and one spiritual), and Esau receives a single material one. Joseph Rackman argues that Isaac intended all along to give Jacob the spiritual blessing of Abraham before Jacob leaves for Laban. ${ }^{114}$ Apologists for Jacob and Rebekah argue that this deception is the quid pro quo for the sale of the birthright. ${ }^{115}$ This third blessing was the one that granted Jacob access to Abraham's initial blessing.

In contrast, Sarah Schwartz argues that this third blessing corresponds with Isaac's preference for Esau, as well as with its contents, giving the firstborn hegemony over the household. ${ }^{116}$ The blessing purports to give Esau lordship over the other children, and over material wealth. After the deceit was discovered, all Isaac could do was to subjugate Esau to Jacob and acknowledge his future lack of monetary advantage since Jacob would now receive a double portion and not Esau. Schwartz further argues (contra Rackman, see below) that Isaac made a deliberate choice to give it to Esau since as father he has the authority to decide the matter. Esau was the obvious choice, but not necessarily the only possibility. Isaac could have given it to Jacob too, but his choice was most probably influenced by his love for game and Esau's ability to feed him. ${ }^{117}$

However, if Isaac intended to give Abraham's blessing to Jacob and not to Esau, why did Rebekah then caused Jacob to deceive Isaac? Did she not know what Isaac's intention was? According to Rackman, Rebekah believed that the material and the spiritual blessing should go together. ${ }^{118}$ Herself being a working girl (when Eliezer met her, she was herding animals), she thought the spiritual blessing was insufficient. Jacob needed the means to sustain himself. Rackman argues, from the point of view of Isaac, that he does not want to leave out one of his sons as his father did once with Ishmael. In the end, according to Rackman, they interpreted the initial prophecy during the pregnancy differently: Rebekah interpreted it literally, namely that the older brother Esau will serve the younger brother Jacob. However, Isaac believed that both should serve the deity equally, with Esau the exemplar of power and materialism, and Jacob the exemplar of

113 Ibid., 133.

114 Joseph Rackman, “Was Isaac Deceived?” Judaism 43/1 (1994): 37-45.

115 Ibid., 42.

116 Sarah Schwartz, "Isaac's Dual Test in the Blessings Narrative: A New Reading of Gen 27:18-29," JSOT 43/4 (2019): 700-1.

117 Schwartz, "Isaac's Dual Test in the Blessings Narrative," 703.

118 Rackman, "Was Isaac Deceived?"39. 
study and spirituality. ${ }^{119}$ Spero adds that it is not entirely clear what Esau lost, and Jacob gained in the process of deception and the birthright sale. ${ }^{120} \mathrm{He}$ agrees with Rackman's view that Isaac never intended to give the Abrahamic blessing to Esau in any case.

But how should one then understand the identity tests in the blessings narrative? I think Schwartz elegantly proves through her literary analysis how Isaac tries to be convinced that the person in front of him was indeed Esau:

This structure affords equal significance to both of the external characteristics that not only serve Isaac in his identification of Esau but also indicate Esau's qualities: hairy hands and the scent of the field are central elements in the design of Esau's character as a powerful man who is connected to the land. These characteristics convince Isaac that Esau is the son before him, and they are also the reason for the blessing. Thus, the structure of the scene and the centrality of Isaac therein expose Isaac's motives for selecting Esau for the birthright blessings. ${ }^{121}$

One can then argue that Isaac originally intended to give Esau the blessing, but his attempt was thwarted by Rebekah and Jacob.

\section{E CONCLUSION}

The question I asked in the introduction was: Who perverts justice, and for whom should the readers reserve their disgust? I also asked whether it is possible that: (i) Rebekah and Jacob deceived Isaac and robbed Esau of his blessing; (ii) Jacob exploited Esau to gain the birthright; (iii) Esau did not care enough; or (iv) whether Isaac neglected his role as patriarch.

My point of departure was my own socio-historical location, namely that of white masculinity, which is a specific socio-historical position within a decolonial framework. I linked that to the rhetoric of disgust as exemplified in the year 2020 in the Republic of South Africa. The notion of moral injury relates me to Jacob's position of a chancer (kansvatter) when his mother enticed him to be complicit in the deceit of Isaac. Yet, the story reserves its disgust for Esau not regarding his birthright highly, and in a racist way implies that his marriage to Hittite women as inappropriate. Esau is the one experiencing the ball end of the hammer of the deceit committed by his mother and brother.

The interpretations I discussed confronted me with the following dilemma: Jacob receives the blessing of the Abrahamic covenant, but some readers exonerate him and his mother for the way it was achieved as if the blessed

\footnotetext{
119 Ibid., 44.

120 Spero, "Jacob and Esau," 247.

121 Schwartz, "Isaac's Dual Test in the Blessings Narrative," 710.
} 
was divinely appointed. The story leaves me with a measure of disgust towards Rebekah and Jacob, and sympathy for Esau. Some interpretations employed the notion of "Disneyfication" - the piety of Rebekah and Jacob, and the disgust for Esau, construct an aura of innocence and adventure in specific interpretations of the story cycle. Giroux argues the following about Disney animation films:

The cultural authority of this postmodern mediascape rests on its power to usurp traditional sites of learning and its ability to expand the power of culture through an endless stream of signifying practices that prioritise the pleasures of the image over the intellectual demands of critical inquiry. Moreover, it simultaneously reduces the demands of human agency to the ethos of facile consumerism. This is a media apparatus in which the past is filtered through an appeal to cultural homogeneity and historical purity, which erases complex issues, cultural differences, and social struggles. ${ }^{122}$

Some interpretations of the story create this kind of innocence that ultimately protects the story from a critical interrogating gaze. It is as if a utopia is created, short of a fantasy world of happiness and coherence - a secure world over against the hard-nosed reality of sustenance living in the story itself. When Giroux asks the Disney company to be held "accountable for how it sells power and manufactures social identities," 123 the question about accountability of Bible readers in terms of the stories they interpret or retell, the images they create, their representations and values they offer in the retelling of the biblical stories are also placed under scrutiny.

My socio-historical location of white masculinity attributes to me a certain role whether I like it or not, namely the object of disgust as a perpetrator of racism. The Jacob-Esau cycle reminded me yet again of the reason for the disgust for Esau, namely a counterfoil in the Persian period for the vicissitudes of what happened in the province of Yehud and the imaginary construction of a biblical Israel. However, linking Rebekah and Jacob's actions directly to the preservation of the covenant with Abraham constitutes in my mind an interpretative abuse and subsequent ethical paralysis within those who would follow such a reading. Moreover, the deity is drawn into the ruse and by implication made complicit in the deceit.

With the interpretations at my disposal, I did not find any critique on the narrator's perspective regarding the negative remark about the ethnicity of Esau's wives. I doubt whether this will be an issue within the discourse of fundamentalism, despite the smell of racism in the biblical text. However, a reference like this and a failure to pick it up in a post-apartheid theological

\footnotetext{
122 Giroux, "Animating Youth," 66.

123 Ibid, 75-6.
} 
endeavour make the development of a post-apartheid theology within the field of whiteness problematical.

I view disgust here as a moral emotion that developed through learning and cultivation from a bodily experience. This is the case Eva Levavi Feinstein makes when she situates disgust in the context of ancient Israel. As a reader, I cannot side with the narrator in his disgust for Esau, but I understand Esau's position very well given the history of apartheid and racism and the feelings of disgust the remarks on apartheid such as those of De Klerk generated. My anger is not towards those expressing such feelings, but to the tradition in which De Klerk stands, which gave birth to apartheid and racism.

But disgust also brings me into conflict with my theological tradition, notably the doctrine of predestination and the ease with which the effect of the deceit on Esau is settled. Predestination provides an easy ride towards the justification of discrimination against others: the deity takes sides against those he rejects. Somehow, the rejected becomes easy targets for deceit in the story. The unworthiness of one enhances the worthiness of another. The argument that Esau lacked a specific spirituality sounds very similar to decolonial discourse's distinction between the zones of being and non-being. In my mind there is nothing in the story that characterises the spirituality of Jacob or Esau. If the problem was Esau's Hittite wives, why did Isaac not send out someone to search for a wife that would be proper according to the covenant? Was Esau set up for failure from the beginning, so that he did not really matter in the end? Over against this, the story clearly states that Jacob mattered.

Empathising with Esau allows a reader to become vulnerable with Esau and a reading against the grain of the story reveals all the socio-political prejudices and theological presuppositions with which one engages the text. Such vulnerability opens the door to change and to think differently, even to rethink the theological tradition in which one stands.

\section{F BIBLIOGRAPHY}

Anderson, Bradford A. "Jacob, Esau, and the Constructive Possibilities of the Other." Biblical Theology Bulletin 49/1 (2019): 16-21.

Baines, Ronald. “'Praedicatio Verbi Dei Est Verbum Dei:' The Preaching Of The Word Of God Is The Word Of God - Heinrich Bullinger And The Second Helvetic Confession." Journal of the Institute of Reformed Baptist Studies 2 (2015): online: https://www.galaxie.com/article/jirbs02-0-02.

Boone, Kathleen C. The Bible Tells Them So. The Discourse of Protestant Fundamentalism. London: SCM Press, 1990.

Bridge, Edward J. "The 'Slave' is the 'Master': Jacob's Servile Language to Esau in Genesis 33.1-17." Journal for the Study of the Old Testament 38/3 (2014): 26378. 
Calvin, Jean. L'institution Chrétienne. Le Troisième Livre De L'Institution Chrétienne de la Manière de Participer à la Grâce de Jésus-Christ, des Fruits qui Nous en Reviennement et des Effets qui s'en ensuivent. Genève: Editions Kerygma et Farel, 1978.

Critchell, Kara; Knittel, Susanne C., Perra, Emiliano; Üngör, Ugur Ümut. "Editor's Introduction." Journal of Perpetrator Research 1/1 (2017): 1-27.

Elazar, Daniel J. "Jacob and Esau and the Emergence of the Jewish People." Judaism 43/3 (1994): 294-301.

Feinstein, Eva Levavi. Sexual Pollution in the Hebrew Bible. Oxford: Oxford University Press, 2014.

Freddy Fritz. "Jacob's Deception of Isaac." (2017): Accessed 23 March 2020. https://www.sermoncentral.com/sermons/jacob-s-deception-of-isaac-freddyfritz-sermon-on-deception-227090.

Giroux, Henri. “Animating Youth. The Disneyfication of Children's Culture.” Socialist Review-San Francisco 24 (1994): 65-79.

Greenberger, Chaya. "Esau and Jacob: Brothers Clash, Reconcile and Separate." Jewish Bible Quarterly 46/3 (2018): 144-57.

Haidt, Jonathan; Paul Rozin; Clark McCauley; and Sumio Imada. "Body, Psyche, and Culture: The Relationship Between Disgust and Morality." Psychology and Developing Societies 9/1 (1997): 107-31.

Norbrook, David, ed. Order and Disorder Oxford: Blackwell, 2001.

Hyman, Ronald. "Comment on 'the God of Abraham, Rebekah, and Jacob." Jewish Bible Quarterly 33/1 (2005): 61-64.

Inbinder, Gary. "Jacob and Esau." Humanitas 26/1 (2003): 90-96.

Kass, Leon R. "A Woman for All Seasons," Commentrary 92/3 (1991): 30-35.

Koorts, Lindie. "No Shame, No Remorse: How Afrikaners Are Dealing with Their Apartheid Past." News24, 2020.

Kratz, Matthew. "Rebekah: The Mother of Jacob and Esau." (2014): Accessed 23 March 2020. https://www. sermoncentral.com/sermons/print? sermonId =208912.

Krog, Antjie. "FW De Klerk Never Had Any Moral Intention, and He Left Us Behind as White Kansvatters." News24, 2020.

Levi, Primo. The Drowned and the Saved. New York: Vintage Books, 1989.

Looy, Heather. "Embodies and Embedded Morality: Divinity, Identity, and Disgust." Zygon 39/1 (2004): 219-35.

Matalon, Guy. "Rebekah's Hoax.” Jewish Bible Quarterly 36/4 (2008): 243-51.

Morgenstern, Matthias. "The Image of Edom in Midrash Bereshit Rabbah" Revue de l'Histoire des Religions (Online) 2 (2016): 193-222.

Navon, Mois A. "The Kiss of Esau." The Jewish Bible Quarterly 35/2 (2007): 128-31.

Ngqakamba, Sesona. "Timeline: $\mathrm{Fw}$ De Klerk: Tracking the Storm," Https://www.news24.com/southafrica/news/timeline-Fw-de-klerk-tracking-thestorm-20200217." The Citizen, 2020.

Paul Rozin and April E. Fallon. “A Perspective in Disgust." Psychological Review 94/1 (1987): 23-41.

Phamodi, Sekoetlane. 'Opinion: Hermanus's Acclaimed 'Moffie' is Probably Not for Black Queers.” okayafrica.com (2020): https://www.okayafrica.com/southafrica.

Rackman, Joseph. “Was Isaac Deceived?” Judaism 43/1 (1994): 37-45. 
Reiss, Moshe. "The God of Abraham, Rebekah and Jacob." Jewish Bible Quarterly 32/2 (2004): 91-97.

Rozin, Paul; Carol Nemeroff; Matthew Horowitz; Bonnie Gordon; and Wendy Voet. "The Borders of the Self: Contamination Sensitivity and Potency of the Body Aperture and Other Body Parts." Journal of Research in Personality 29 (1995): 318-40.

Saayman, Chris. “Genesis 27: Die Mens Wik Maar God Beskik.” Preke: Genesis reeks no 26 (2019): Accessed 23 March 2020. http://www.tafelbergkerk .co.za/sermon/genesis-reeks-no-26-die-mens-wik-maar-god-beskik/.

Schindler, Pesach. "Esau and Jacob Revisited: Demon Versus Tzadik?" Jewish Bible Quarterly 35/3 (2007): 153-60.

Schwartz, Sarah. "Isaac's Dual Test in the Blessings Narrative: A New Reading of Gen 27:18-29." Journal for the Study of the Old Testament 43/4 (2019): 693-711.

Shay, Jonathan. Achilles in Vietnam. Combat Trauma and the Undoing of Character. New York: Touchstone Books, 1995.

Shook, Lauren. "'Pious Fraud': Genesis Matriarchs and the Typological Imagination in Lucy Hutchinson's Order and Disorder." Modern Philology 112/1 (2014): 179204.

Smith, Craig A. "Reinstating Isaac: The Centrality of Abraham's Son in the 'JacobEsau' Narrative of Genesis 27." Biblical Theology Bulletin 31/4 (2001): 130-35.

Danie Snyman. "Agter Ons Lewens Lê God Se Beskikking," (2012): Accessed 23 March 2020. http://www.gkmagalieskruin.co.za/View/ShowDoc.aspx?WebID $=101 \&$ Image ID $=470$.

Snyman, Fanie (S.D.). Malachi. Leuven: Peeters, 2014.

Snyman, Gerrie F. "Perpetrator Silence: Obadiah's Depiction of Israel as Victim and Edom as Perpetrator." Vulnerability and Resilience (2021): To be published. . "The Ethics of Reading the Bible: Vulnerability in and Moral Injury of Whiteness in (White) Bible Reading. Paper Read at Conference on the Abuse of Religion and the Gullibility of the Public at Unisa in March 2019." Alternation (2020): To be published.

. "Read as/with the Perpetrator: Manasseh's Vulnerability in 2 Kings 21:1-18 and 2 Chronicles 33:1-20." Scriptura 116 (2017): 188-207.

. "Obadiah and a Hermeneutic of Vulnerability," In Obadiah, edited by Bob Becking, 45-63. Sheffield: Sheffield Phoenix Press, 2016.

"A Hermeneutic of Vulnerability: Edom in Malachi 1:2-5." Journal for Semitics 25/1 (2016): 595-629.

“A Hermeneutic of Vulnerability: Redeeming Cain?" Stellenbosch Theological Journal 1/2-3 (2015): 633-65.

Spector, Brooks. "The Four Ages of Frederik Willem De Klerk.” Daily Maverick, 2020.

Spero, Shubert. "Jacob and Esau: The Relationship Reconsidered." Jewish Bible Quarterly 32/4 (2004): 245-50.

Weiss, Shira. "The Ethics of Price Gouging. Jacob's Purchase of Esau's Birthright." Journal of Religious Ethics 45/1 (2017): 142-63.

Wiinikka-Lydon, Joseph. "Moral Injury as Inherent Political Critique: The Prophetic Possibilities of a New Term." Political Theology 18 (2017): 219-32.

Wiinikka-Lydon, Joseph. "Dirty Hands and Moral Injury." The Royal Institute of Philosophy 93 (2018): 355-74. 
472 Snyman, "Perverters of Justice," OTE 33/3 (2020): 445-472

Zakovich, Yair. "Disgrace. The Lies of the Patriach." Social Research 75/4 (2008): 1035-58.

Zucker, David J. "The Deceiver Deceived: Rereading Genesis 27." Jewish Bible Quarterly 39/1 (2011): 46-58.

Zvi, Ehud Ben. "Edom as a Complex Site of Memory Among the Literati of Late Persian/early Hellenistic Judah: Some Observations." https://www.academia .edu/40823705/BenZvi_Edom_as_a_Complex_Site_of_Memory_academia .edu_version, 2020.

Prof. Gerrie F. Snyman is a professor in Old Testament in the Department of Biblical and Ancient Studies at the University of South Africa. Email: gfsnyman@global.co.za or snymagf@unisa.ac.za. ORCID: https://orcid.org/0000-0001-5145-2822. 